\title{
Growth Performance and Yield of Oyster Mushroom (Pleurotus Ostreatus) on Different Substrates Composition in Buea South West Cameroon
}

\author{
${ }^{1}$ Ajonina A. Samuel, ${ }^{2}$ Tatah L. Eugene \\ ${ }^{1}$ Department of Environmental Sciences, University of Buea P.0 Box 63 Buea Cameroon \\ ${ }^{2}$ Department of Crop Production, University Institute for the Diocese of Buea
}

Accepted $17^{\text {th }}$ March, 2012

\begin{abstract}
Mushrooms are increasingly becoming an important component of diets worldwide and it is of paramount importance to choose appropriate substrates in a given place to grow them. The experiment was conducted at the Cameroon Society for Sustainable Development of Natural Resources and Environmental Projection (CASSDNREP) mushroom department farm. The main goal was to evaluate the growth performance of oyster mushroom (Pleurotus ostreatus) on some locally available substrate material compositions as well as to find out the best substrate for mushroom cultivation. Bags were sterilised in 1000 litres iron containers for $5 \mathrm{~h}$ at $100^{\circ} \mathrm{C}$, cooled for $6 \mathrm{~h}$ and then inoculated with actively growing mushroom mother culture on rice grains obtained from Mushroom Cameroon, Bamenda. The bags were incubated until mycelium had fully colonized the substrate and then taken to the cropping house. The highest mycelium running rate was found on Corn cobs and palm cones (1:1) but the lowest in control. Completion of mycelium running time was lowest in $(1: 3,3: 1$ and palm cones). Number of total primordia and effective primordia, found highest in control but the highest pileus thickness was measured from corn cobs. Highest biological yield (146.1 g and $172.1 \mathrm{~g}$ ) was obtained from corn cones which was much higher than control.
\end{abstract}

Keywords: Corn cobs, Palm cones, Growth Performance, Yield and Pleurotus ostreatus

\section{Introduction}

The Egyptians considered mushrooms as a delicacy reserved for Pharaohs while the Romans ate mushrooms at feasts and believed that mushrooms provided strength for warriors in battle (Jahan et al., 2010) and in the far East mushrooms are venerated for their medicinal value (Chang and Miles, 2004). Mushrooms can be picked from the wild during the latter wettest part of the rainy season, where they are found growing on deeply decomposing organic matter. However not all mushrooms found growing in the wild are good for human consumption. Some are edible, but other species are poisonous making people sceptical about their consumption in general (Oei, 1996). Growing of safe known mushrooms therefore, presents a window of opportunity. Mushroom cultivation is a profitable agri-business and Oyster mushroom (Pleurotus ostreatus) is an edible mushroom having an excellent taste and flavour. It belongs to the class
Basidiomycetes, subclass Hollobasidiomycetidae, order Agricales. It grows wild in the forest and is cultivated in the temperate and sub tropical regions of the world (Ayodele and Akpaja, 2007). The technology of artificial mushroom cultivation is a recent innovation, which stemmed from the realization that the incorporation of non-conventional crops in existing agricultural systems can help in improving the social as well as the economic status of small farmers. Mushrooms are a delicacy and are used in the preparation of many continental dishes. They have anticancerous, anticholesterol and antitumorous properties and are useful against diabetes, ulcer and lung diseases (Quimio, 1980). Mushrooms are a good source of protein, vitamins and minerals (Kimenju et al., 2009.). Mushrooms contain about $85-95 \%$ water, 3\% Protein, 4\% Carbohydrates, $0.1 \%$ fats, $1 \%$ minerals and vitamins (Palapala et al., 2006). They also contain appreciable amounts of potassium, phosphorus, copper and iron but have low levels of calcium. Mushroom protein is intermediate between that of animals and vegetables (Kurtzman, 1976 cited in Bauh et al., 2010). Oyster mushroom has no starch, low sugar content and high amount of fibre, hence it serves as the least fattening food (Osei, 1996). In Cameroon, wild mushroom has been a delicacy for many years. It is regarded as meat substitute especially by the rural population of Cameroon). With changes in the climatic patterns, it is becoming difficult harvesting wild mushrooms. The alternative then, is to grow mushrooms domestically. In Cameroon, Oyster mushrooms have become the most popular for commercial production. The growth of oyster mushroom requires high humidity $(80-90 \%)$ and high temperature $\left(25-30^{\circ} \mathrm{C}\right)$ for the vegetative growth called spawn running and lower temperature $\left(18-25^{\circ} \mathrm{C}\right)$ for fruit body formation, Onyango et al., (2011) like other mushrooms, oyster mushroom can be grown on various agricultural waste with the use of different technologies. Mushroom substrate may be defined as a kind of lingo cellulose material which supports the growth, development and fruiting of mushroom (Chang and Miles, 1988).

In Cameroon, the main common substrate for the production of mushroom is sawdust. Sawdust is a mixture of shavings from many trees and depending on the type of tree and the amount of lignin present, the growth of the 
spawn can be inhibited. Moreover, with the increasing expansion in the poultry industry, there is high demand for sawdust, hence making it difficult and expensive for potential commercial mushroom growers to get enough sawdust. One farm produce that is easily available in Cameroon at all times is the corn cob and stalks. During the main harvesting period, corn cobs and stalks are in abundance and farmers dispose of them by burning. If grounded corn cob can support the growth of oyster mushroom, then it would serve as a cheap source of substrate for mushroom growers. The grounded form of corncob is very firm and retains good amount of moisture to make it a plausible alternative to sawdust (Buah et al.,2010). The experiment was conducted on palm cones and corn cobs at various compositions with a view to determine the cheapest substrate with best yield performance.

Table 1: The growth of Pleurotus ostreatus on six different substrates with a control

\begin{tabular}{|c|c|c|}
\hline S. no & Substrates & Composition \\
\hline 1 & Substrates 1 & Palm cones (100\%) \\
\hline 2 & Substrates 2 & Corn cobs (100\%) \\
\hline 3 & Substrates 3 & Corn cobs \&Palm cones (1:1) \\
\hline 4 & Substrates 4 & Corn cobs \& Palm cones (1:3) \\
\hline 5 & Substrates 5 & Corn cobs \& Palm cones (3:1) \\
\hline 6 & Substrate (Control) & $\begin{array}{c}\text { Saw dust: coffee husk: wheat } \\
\text { bran }(6: 3: 1)\end{array}$ \\
\hline
\end{tabular}

\section{Materials And Methods}

The research was conducted at Cameroon Society for Sustainable Development of Natural Resources and Environmental Protection (CASSDNREP) Mushroom farm Buea, Cameroon from September 2011 to November 2011.

\section{Preparation of sawdust:}

The sawdust obtained from carpenter shops at mile 16 Buea was mixed with ground wheat bran and coffee husk in a ratio of $(6: 3: 1)$ then supplemented with $1.5 \mathrm{~kg}$ of soya bean cake and $0.1 \mathrm{~kg}$ of quick lime. The materials were mixed thoroughly on cemented floor using the hands. The moisture was increased by adding water until it reached around $65 \%$ moisture content. Then polypropylene bags $(25 \times 18 \mathrm{~cm})$ were filled with $2.3 \mathrm{~kg}$ prepared substrate and packed tightly. A hole of 3 to $5 \mathrm{~cm}$ was made with a stainless steel knife at the centre for space to put the inoculums. The packets were sterilized in drums at 80 to $100^{\circ} \mathrm{C}$ for 5 hours and were kept 8 hours for cooling. One table spoonful of mother culture materials containing mycelia was placed aseptically through the hole of each packet separately and each treatment was replicated 4 times. The packets were then marked treatment wise with a permanent marker pen and were kept on the shelves in an incubation room at $25 \pm 1$ ${ }^{\circ} \mathrm{C}$ under $80 \%$ to $85 \%$ relative humidity and were allowed to complete the whitish mycelia growth.

\section{Preparation of corn cobs:}

Corn cobs obtained from farms around the University of Buea after sun drying, was reduced into small sizes using a hammer mill at the Department of chemistry University of Buea. The corn cobs were mixed uniformly in a ratio of 1:1 with palm cone wastes obtained from a palm farm at Bunduma Buea. The mixture was supplemented with $1.5 \mathrm{~kg}$ of soya bean cake and $0.1 \mathrm{~kg}$ of quick lime. The materials were mixed thoroughly on a cemented floor and moisture was increased by adding tap water until it reached $65 \%$ moisture content. Polypropylene bags $(25 \times 18 \mathrm{~cm})$ were filled with $2.3 \mathrm{~kg}$ prepared substrate and packed tightly. A hole of 3 to $5 \mathrm{~cm}$ was made with a stainless steel knife at the centre for space to put the inoculums. The bags were sterilized in drums at $100^{\circ} \mathrm{C}$ for 5 hours and were kept to cooling for 6 hours. One table spoonful of mother culture materials containing mycelia was placed aseptically through the hole of each packet separately and each treatment was replicated 4 times. The bags were then marked treatment wise with a permanent marker and were kept on the shelves in an incubation room at $26 \pm 1^{\circ} \mathrm{C}$ under $80 \%$ to $85 \%$ relative humidity and were allowed to complete the whitish mycelia growth under complete darkness.

The same procedure was followed for processing the corn cobs and palm cones (1:3) and corn cobs and palm cones (3:1). Mushroom cultivation has two important phases; spawn running and fructification, while temperature and humidity are two vital factors involved in both phases. The humidity of the bags was accomplished by spraying with water twice a day. The incubation period was about 21 days. The thickening of the mycelia in the bags colonization of the bags was an indication for the bags to be opened for fruiting. The experiment was laid out in a completely randomized design.

\section{Data collection and statistical analysis:}

The experiment was laid out in completely randomized design (CRD) with five treatments and a control with four replications. The data were recorded on mycelium running rate in spawn bags, time required for completion of mycelium running, time required for primordia initiation, time required for harvesting, number of primordia, number of effective fruiting bodies, stalk length, stalk diameter, pileus diameter, pileus thickness, average individual weight of fruiting bodies and biological yield. The data were analyzed by (ANOVA and treatment means were compared

using Duncan's Multiple Range Test i.e. DMRT (Gomez and Gomez, 1984).

\section{Results and Discussion}

Mycelium running rate (MRR) in spawn bags ranged from 0.6132 to $0.8604 \mathrm{~cm} /$ day. The highest mycelium running rate was observed on corn cobs and palm cones $(1: 1)$ which was statistically similar to corn cobs and palm (1:3). The 
lowest mycelium running rate was recorded on control which was statistically similar with corn cobs \& palm cone (3:1) (Table 1). The presence of right proportion of alphacellulose, hemicellulose and lignin was the probable cause of higher rate of mycelium running in corn cobs and palm cones. The substrate, saw dust giving the lowest mycelium running rate might be due to presence of different kinds of polyphenolic substances in them as suggested by Wang (1982) and low content of cellulose (Gohl, 1993). Suitable $\mathrm{C}$ : $\mathrm{N}$ ratio might be responsible for the higher mycelial growth in corn cobs and palm cones. Quimio and Sardsud (1981) reported similar results, whereby the optimum

Table 2. The effect of different substrates on mycelia growth of Oyster mushroom (Pleurotus ostreatus)

\begin{tabular}{|c|c|c|}
\hline Substrates & $\begin{array}{l}\text { Mycelium running rate in spawn } \\
\text { bags (cm/day) }\end{array}$ & $\begin{array}{l}\text { Time required for completion of } \\
\text { mycelium running (days) }\end{array}$ \\
\hline Palm cones (100\%) & $0.6403 \mathrm{ab}$ & $21.00 \mathrm{~d}$ \\
\hline Corn cobs (100\%) & $0.6002 \mathrm{~b}$ & $23.00 \mathrm{~b}$ \\
\hline Corn cobs and palm cones $(1: 1)$ & $0.7538 \mathrm{a}$ & $22.45 \mathrm{c}$ \\
\hline Corn cobs and palm cone $(1: 3)$ & $0.6301 \mathrm{ab}$ & $21.00 \mathrm{~d}$ \\
\hline Corn cobs and palm cone 3:1 & $0.5929 \mathrm{c}$ & $21.00 \mathrm{~d}$ \\
\hline Saw dust (Control) & $0.5794 \mathrm{c}$ & $24.06 \mathrm{a}$ \\
\hline Significance & $* *$ & $* *$ \\
\hline CV $(\%)$ & 5.09 & 2.24 \\
\hline
\end{tabular}

\section{Time (days) required for completion of mycelium} running:

Days to complete mycelium running in spawn bags ranged 21.00 days to 24.06 days on different substrates (Table 1 ). Significantly the lowest days to complete mycelium running was recorded on corn cobs and palm cones (1:3), corn cobs and palm cones $(3: 1)$ and palm cones $(100 \%)$. Highest days (24.06) was required to complete mycelium running on control, which was significantly different from other substrates (Table 1). The appreciable days to complete mycelium running of oyster mushroom on different substrates might be due to variation in their chemical composition and C: $\mathrm{N}$ ratio as reported by Bhatti et al. (1987) cited in Mondal et al (2010). The results recorded on all substrates were very closed to the findings of Shah et al. (2004) Mondal et al., (2010) who reported that the spawn running took $16-25$ and 21 to 24.75 days after inoculation.
However, the results from this study did not agree with those obtained by Buah et al., (2010) who reported that the spawn running took 15.67 to 18.53 days after inoculation

\section{Time required for primordia initiation:}

The lowest time (5.80 days) for primordia initiation recorded on control which was statistically similar with corn cobs and palm cones in both (1:3) and (3:1) ratio. The highest time for primordia initiation was found in $100 \%$ corn cobs (Table 2). Mondal et al.,(2010) found that the spawn heads appeared 5.50 days after the spawn running. Ahmed (1998) stated that P. ostreatus completed spawn running in 17-20 days on different substrates and time for pinhead formation was noted at 23-27 days. whereas Buah et al., (2010) reported pinhead formation of P. ostreatus on different substrates after 21-23 days.

Table 3. Effect of different substrates on time required for primordia initiation and time required for harvesting

\begin{tabular}{|c|c|c|}
\hline Substrates & $\begin{array}{l}\text { Time required for primordia } \\
\text { initiation (days) }\end{array}$ & Time required for harvesting (days) \\
\hline Palm cones $(100 \%)$ & $5.99 \mathrm{~b}$ & $9.78 \mathrm{ab}$ \\
\hline Corn cobs $(100 \%)$ & $8.01 \mathrm{a}$ & $10.92 \mathrm{~b}$ \\
\hline Corn cobs and palm cones $(1: 1)$ & $7.73 \mathrm{a}$ & $11.60 \mathrm{c}$ \\
\hline Corn cobs and palm cone $(1: 3)$ & $6.23 \mathrm{c}$ & $9.88 \mathrm{ab}$ \\
\hline Corn cobs and palm cone 3:1 & $6.11 \mathrm{c}$ & $10.02 \mathrm{a}$ \\
\hline Saw dust (Control) & $5.80 \mathrm{c}$ & $6.71 \mathrm{c}$ \\
\hline Significance & $* *$ & $* *$ \\
\hline CV $(\%)$ & 5.89 & 4.97 \\
\hline
\end{tabular}

The 1st flush number of total primordia ranged from 26.45 to 44 . 50. The highest number of primordia was recorded on sawdust substrate. The lowest number of total primordia was recorded on palm cones which was statistically similar with corn cobs and palm cones in ratio of 1:3 (Table 3). On the other hand in 2nd flush number of total primordia was highest (57.61) on sawdust. The lowest number (31.00) of total primordia was recorded on palm cones. The number of total primordia in the 3 rd flush ranged from 30.65 to
41.05 and the highest number was recorded on corn cobs and palm cones which was statistically similar with sawdust (Table 3). The lowest number was recorded on corn cobs and palm cones (1:3). From the results obtained it was observed that the highest number (57.61) of total primordia was recorded in the $2 \mathrm{nd}$ flush on control. The lowest number of primordia (31.00) was recorded in the first flush on palm cones (Table 3 ). 
Table 4. Number of primordia and effective fruiting bodv as affected bv different substrates

\begin{tabular}{|c|c|c|c|c|c|c|}
\hline \multirow{2}{*}{ Substrates } & \multicolumn{3}{|c|}{ No. of total primordia } & \multicolumn{3}{|c|}{ No. of effective fruiting body } \\
\hline & Flush 1 & Flush 2 & Flush 3 & Flush 1 & Flush 2 & Flush 3 \\
\hline $\begin{array}{|ll|}\text { Palm } & \text { cones } \\
(100 \%) & \\
\end{array}$ & $26.45 a$ & $31.5 b$ & $30.65 b$ & $9.20 \mathrm{~d}$ & $11.95 c$ & $9.90 \mathrm{~cd}$ \\
\hline $\begin{array}{ll}\begin{array}{l}\text { Corn } \\
(100 \%)\end{array} & \text { cobs } \\
\end{array}$ & $28.02 \mathrm{a}$ & $47.00 \mathrm{~b}$ & 39.86.c & $24.00 \mathrm{c}$ & $37.42 .00 \mathrm{a}$ & $29.00 \mathrm{~cd}$ \\
\hline $\begin{array}{|lr|}\text { Corn } & \text { cobs \& } \\
\text { Palm } & \text { cones } \\
(1: 1) & \\
\end{array}$ & 36.98 & $43 \cdot 00$ & 38.69 & $27.50 \mathrm{~b}$ & $28.00 \mathrm{~b}$ & $19.50 \mathrm{c}$ \\
\hline 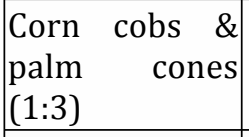 & 26.73 & 39.05 & $36 \cdot 00$ & $9.00 \mathrm{~d}$ & $19.75 b$ & $10.75 d$ \\
\hline $\begin{array}{|lr|}\text { Corn } & \text { cobs \& } \\
\text { palm } & \text { cones } \\
(3: 1) & \\
\end{array}$ & 29. & 40.01 & 41.03 & $10.50 \mathrm{~d}$ & $14.00 \mathrm{~b}$ & $13.5 c$ \\
\hline $\begin{array}{|ll|}\begin{array}{ll}\text { Saw } & \text { dust } \\
\text { (Control) }\end{array} \\
\end{array}$ & $44 \cdot 50$ & 57.61 & 40.97 & $36.26 a$ & $21.25 b$ & $17.25 \mathrm{~b}$ \\
\hline \begin{tabular}{|l|l} 
Significance \\
\end{tabular} & $* *$ & $* *$ & $* *$ & $* *$ & $* *$ & $* *$ \\
\hline CV\% & 8.91 & 11.01 & 10.88 & 7.04 & 5.58 & 9.77 \\
\hline
\end{tabular}

\section{Number of effective fruiting body:}

The fruiting body is the edible part of mushroom. The results showed significant variability on the different substrate compositions used under this study (Table 3). In the first flush, the number of effective fruiting body ranged from 9.20 to 36.26 and the highest number of effective fruiting body was recorded on sawdust. The lowest number of effective fruiting body was recorded on palm cones. In the second flush, the number of effective fruiting body was recorded highest (37.42) on corn cobs. The lowest number (11.95) was recorded on palm cones. In the third flush, the number of effective fruiting body ranged from 9.90 to 29.00 . The highest number was recorded on corn cobs and the lowest number was recorded on palm cones. This result obtained for effective fruiting body might be due to the presence of glucose, fructose and trehalose in the substrate, as reported by Kitamoto et al (1995). Experimental findings by Poppe (1973) indicated that Indole Acetic Acid (IAA) increases the number of fruiting body of mushroom.

\section{Stalk length:}

Stalk length of P. ostreatus differed on the different substrates compositions at $1 \%$ level of significance. In the first flush, the highest stalk length was recorded on sawdust which was statistically similar with corn cobs, corn cobs and palm cones (1:1) and corn cobs and palm cones (3:1). The lowest stalk length was recorded on corn cobs and palm cones (1:3), which was statistically similar with palm cones (Table 4). In the second flush the highest stalk length was recorded on corn cobs which statistically similar to corn cobs and palm cones (1:3). In the third flush the highest stalk length was recorded on sawdust and lowest figure for stalk length was recorded on palm cones. Among the three flushes, the highest stalk length $(3.90 \mathrm{~cm})$ was found in sawdust of first flush and the lowest $(1.91 \mathrm{~cm})$ was recorded in palm cones of third flush (Table 4). Oyster Mushroom (Pleurotus ostreatus) quality depends on the length of stalk Zadrazil (1978) cited in Mondal et al., (2010) found out that the higher the stalk length, the poorer the quality of the mushroom.

Table 5. Effect of different substrates on some yield attributes of oyster mushroom

\begin{tabular}{|l|l|l|l|l|l|l|l|l|l|}
\hline \multirow{2}{*}{ Substrates } & \multicolumn{3}{|l}{ Stalk length $(\mathrm{cm})$} & \multicolumn{3}{l|}{ Pileus diameter $(\mathrm{cm})$} & \multicolumn{3}{|l|}{ Pileus thickness (cm) } \\
\cline { 2 - 10 } & Flush 1 & Flush 2 & Flush 3 & Flush 1 & Flush 2 & Flush 3 & Flush 1 & Flush 2 & Flush 3 \\
\hline $\begin{array}{l}\text { Palm cones } \\
(100 \%)\end{array}$ & $2.79 \mathrm{bc}$ & $2.42 \mathrm{~d}$ & $1.91 \mathrm{~b}$ & $3.68 \mathrm{bc}$ & $2.94 \mathrm{c}$ & $3.45 \mathrm{~b}$ & $0.647 \mathrm{~b}$ & $0.62 \mathrm{a}$ & $0.559 \mathrm{a}$ \\
\hline $\begin{array}{l}\text { Corn cobs } \\
(100 \%)\end{array}$ & $3.75 \mathrm{ab}$ & $3.83 \mathrm{c}$ & $2.00 \mathrm{~b}$ & $3.89 \mathrm{~b}$ & $2.89 \mathrm{c}$ & $3.49 \mathrm{~b}$ & $0.670 \mathrm{ab}$ & $0.64 \mathrm{a}$ & $0.561 \mathrm{a}$ \\
\hline $\begin{array}{l}\text { Corn cobs } \\
\& \quad \text { Palm } \\
\text { cones }(1: 1)\end{array}$ & $3.06 \mathrm{ab}$ & $2.08 \mathrm{~cd}$ & $2.97 \mathrm{a}$ & $3.18 \mathrm{c}$ & $3.13 \mathrm{bc}$ & $3.12 \mathrm{~b}$ & $0.660 \mathrm{ab}$ & $0.62 \mathrm{a}$ & $0.440 \mathrm{~b}$ \\
\hline
\end{tabular}




\begin{tabular}{|c|c|c|c|c|c|c|c|c|c|}
\hline $\begin{array}{c}\text { Corn cobs } \\
\& \text { Palm } \\
\text { cones } \\
(1: 3)\end{array}$ & $2.57 \mathrm{c}$ & $3.81 \mathrm{a}$ & $2.99 \mathrm{a}$ & $3.93 \mathrm{~b}$ & $3.45 \mathrm{ab}$ & $4.36 \mathrm{a}$ & $0.640 \mathrm{ab}$ & $0.43 \mathrm{~b}$ & $0.520 \mathrm{a}$ \\
\hline $\begin{array}{c}\text { Corn cobs } \\
\text { \& Palm } \\
\text { cones } \\
(3: 1)\end{array}$ & $3.60 \mathrm{a}$ & $2.66 \mathrm{~cd}$ & $2.91 \mathrm{a}$ & $3.49 \mathrm{bc}$ & $3.40 \mathrm{c}$ & $4.36 \mathrm{a}$ & $0.660 \mathrm{a}$ & $0.58 \mathrm{a}$ & $0.548 \mathrm{a}$ \\
\hline $\begin{array}{c}\text { Saw dust } \\
\text { (Control) }\end{array}$ & $3.90 \mathrm{a}$ & $3.34 \mathrm{~b}$ & $3.10 \mathrm{a}$ & $5.69 \mathrm{a}$ & $3.68 \mathrm{a}$ & $3.57 \mathrm{~b}$ & $0.350 \mathrm{c}$ & $0.49 \mathrm{~b}$ & $0.410 \mathrm{~b}$ \\
\hline $\begin{array}{c}\text { Significa } \\
\text { nce }\end{array}$ & $* *$ & $* *$ & $* *$ & $* *$ & $* *$ & $* *$ & $* *$ & $* *$ & $* *$ \\
\hline CV (\%) & 10.92 & 6.05 & 7.91 & 3.62 & 6.24 & 6.33 & 7.39 & 5.11 & 5.01 \\
\hline
\end{tabular}

Pileus diameter:

The diameter of the pileus differed on the different substrates. In the first flush, the pileus diameter was highest $(5.69 \mathrm{~cm})$ on sawdust and lowest $(3.18 \mathrm{~cm})$ diameter was recorded on corn cobs and palm cones (1:1). In the second flush, the pileus diameter ranged from $2.89 \mathrm{~cm}$ to $3.68 \mathrm{~cm}$ (Table 4). The highest diameter was recorded on sawdust while the lowest diameter was recorded on corn cobs. The highest $(4.36 \mathrm{~cm})$ pileus diameter on corn cobs and palm cones $(1: 3)$ which was statistically similar with corn cobs and palm cones $(3: 1)$ and the lowest $(3.12 \mathrm{~cm})$ pileus diameter was recorded on corn cobs and palm cones (1:1) in the third flush. It can be deduced from the study results that the highest $(3.90 \mathrm{~cm})$ diameter was recorded on sawdust in the first flush and the lowest $(1.91 \mathrm{~cm})$ was recorded on palm cones in the third flush (Table 4). Generally as the pileus diameter increases the yield decreases, it was also observed that the pileus diameter of other substrates gave very closed results to the control.

\section{Pileus thickness:}

This is one of the contributing characteristic of mushroom yields. In the first flush the pileus thickness ranged from $0.350 \mathrm{~cm}$ to $0.670 \mathrm{~cm}$ (Table 4). The highest pileus diameter was recorded on corn cobs which was statistically similar with corn cobs and palm cones (1:1) and corn cobs and palm cones (3:1). In the second flush the highest pileus thickness was recorded on corn cobs. The lowest thickness was recorded on corn cobs and palm (1:3). In the third flush the highest recorded pileus thickness was obtained from corn cobs which was statically similar to palm cones, corn cobs (1:3) and corn cobs and palm cones (3:1). From the result it was observed that the highest $(0.670 \mathrm{~cm})$ thickness was recorded corn cobs on the first flush and the lowest $(0.350$ $\mathrm{cm}$ ) was recorded on sawdust on the first flush (Table 4). The control was observed here to give poorer result than other substrates and corn cobs gave the best result among the substrates. Pileus thickness may be higher due to the presence of adequate nutrient in the substrates. Since this is a yield attributing factor, the higher the thickness of the pileus the more the yield may increase.

\section{Weight of individual fruiting body:}

The highest weight in the first flush was recorded on corn cobs and palm cones (3:1) and the lowest was recorded on sawdust (Table 5). While in second flush the highest weight was recorded on corn cobs and palm cones (1:3) which was statistically similar to corn cobs (100\%). The lowest weight was recorded on sawdust which was statistically similar tocorn cobs and palm cones (3:1). In the third flush the weight of individual fruiting body was highest on corn cobs(3:1) and the lowest (3.33 g) weight was recorded on corn cobs and palm cones (1:1).

Table 6. Effect of substrate composition on weight of individual fruiting body and biological yield

\begin{tabular}{|l|c|c|c|c|c|c|}
\hline \multirow{2}{*}{ Substrates } & \multicolumn{2}{|c|}{ Weight of individual fruiting body (g) } & \multicolumn{3}{|c|}{ Biological yield (g) } \\
\cline { 2 - 7 } & Flush 1 & Flush 2 & Flush 3 & Flush 1 & Flush 2 & Flush 3 \\
\hline $\begin{array}{l}\text { Palm cones } \\
(100 \%)\end{array}$ & $6.33 \mathrm{bc}$ & $4.38 \mathrm{bc}$ & $4.46 \mathrm{~b}$ & $35.56 \mathrm{e}$ & $56.16 \mathrm{e}$ & $30.78 \mathrm{c}$ \\
\hline $\begin{array}{l}\text { Corn cobs } \\
(100 \%)\end{array}$ & $7.42 \mathrm{a}$ & $5.43 \mathrm{a}$ & $4.43 \mathrm{~b}$ & $146.1 \mathrm{a}$ & $172.1 \mathrm{a}$ & $81.17 \mathrm{a}$ \\
\hline $\begin{array}{l}\text { Corn cobs \& } \\
\text { Palm cones } \\
(1: 1) \quad 5.71 \mathrm{c}\end{array}$ & $4.79 \mathrm{~b}$ & $3.33 \mathrm{~d}$ & $124.4 \mathrm{~b}$ & $85.93 \mathrm{c}$ & $27.99 \mathrm{c}$ \\
\hline $\begin{array}{l}\text { Corn cobs \& } \\
\text { palm cones } \\
(1: 3) \quad 6.89 \mathrm{ab}\end{array}$ & $5.67 \mathrm{a}$ & $4.67 \mathrm{~b}$ & $27.38 \mathrm{f}$ & $92.32 \mathrm{~b}$ & $27.89 \mathrm{c}$ \\
\hline $\begin{array}{l}\text { Corn cobs \& } \\
\text { palm cones } \\
(3: 1)\end{array}$ & $7.11 \mathrm{ab}$ & $3.98 \mathrm{c}$ & $5.27 \mathrm{a}$ & $47.43 \mathrm{~d}$ & $72.07 \mathrm{~d}$ & $44.57 \mathrm{~b}$ \\
\hline $\begin{array}{l}\text { Saw dust } \\
\text { (Control) }\end{array}$ & $2.78 \mathrm{~d}$ & $3.94 \mathrm{c}$ & $3.88 \mathrm{c}$ & $74.12 \mathrm{c}$ & $72.10 \mathrm{~d}$ & $44.52 \mathrm{~b}$ \\
\hline Significance & $* *$ & $* *$ & $* *$ & $* *$ & $* *$ & $* *$ \\
\hline CV\% & 7.89 & 8.95 & 8.46 & 5.67 & 3.34 & 6.31 \\
\hline
\end{tabular}

How to Cite this Article: Ajonina A. Samuel, Tatah L. Eugene, "Growth Performance and Yield of Oyster Mushroom (Pleurotus Ostreatus) on Different Substrates Composition in Buea South West Cameroon" Science Journal of Biochemistry, Volume 2012, Article ID sjbch-139, 6 Pages, 2012. doi: 10.7237/sjbch/139 


\section{Biological yield:}

The biological yield varied significantly due to the effect of different substrate composition on the different flushes. The highest biological yield (146.1g) was obtained from corn cobs and the lowest biological yield (27.38g) was obtained from corn cobs and palm cones (1:3) in the first flush. Corn cobs also produced the highest biological yield (172.1g) in the second flush. The lowest biological yield (56.16g) was obtained from palm cones which differed significantly from the rest of the substrate compositions in the same flush. In the third flush (100\%) corn cobs yielded the highest biological yield and the lowest biological yield was obtained from corn cobs and palm cones (1:3) which was statistically significant to corn cobs and palm cones (1:1). The overall result, showed that (100\%) corn cobs and corn cobs and palm cones (3:1) yielded better than the control. In (2003), Obodai et al. found eight lignocellulosic by-products as substrates for cultivation of the Oyster mushroom, Pleurotus ostreatus. The yields of mushroom on different substrates were $183.1 \mathrm{~g}, 151.8 \mathrm{~g}, 111.5 \mathrm{~g}, 87.8 \mathrm{~g}$, $49.5 \mathrm{~g}, 23.5 \mathrm{~g}, 13.0 \mathrm{~g}$ and $0.0 \mathrm{~g}$ for composted sawdust of Triplochiton scleroxylon, rice straw, banana leaves, maize stalk, corn husk, rice husk, fresh sawdust and elephant grass respectively and rice straw give the best yield.

\section{References}

1. Ahmed, S. 1998. Development of mushroom varieties suitable for rural level in Bangladesh. Report presented in BARC Annual Review Programme. pp. 72-73.

2. Ayodele, S.M. and E.O. Akpaja, 2007. Yield evaluation of Lentinus squarosulus (Mont) Sing. On selected sawdust of economic tree species supplemented with $20 \%$ oil palm fruit fibres. Asian J. Plant Sci., 6: 1098-1102

3. Bhatti, M.A., Mir, F.A. and Siddiq, M. 1987. Effect of different bedding materials on relative yield of oyster mushroom in the successive flushes. Pakistan J. Agril. Res 8(3): 256-259

4. Bugarski, D., Gvozdenovic, D., Takae, A. and Cervenski, J. 1994. Yield and yield components of different strains of oyster mushroom. Savremena poljoprivreda (Yugoslavia). 42 (1): 314318.

5. Chang, S.T. and P.G. Miles, 2004. Mushrooms: Cultivation, Nutritional Value, Medicinal Effect and Environment Impact. CRC Press, Boca Raton, pp: 415.

6. Chang, S.T. and Miles, P.G. 1988. Edible Mushroom and their cultivation. CRC press, Inc. Boca Raton, Florida U.S.A.27:83-88.

7. Gohl, G. 1993. Tropical Feeds. Published by Food and Agriculture Organization of United Nation. Revised by Andrew speedy computer journal version-4.

8. Gomez, K.A. and Gomez, A.A. 1984. Statistical procedure for Agricultural research. 2nd edition. John Wiley and Sons, New York. $680 \mathrm{P} \mathrm{p}$.

9. Jahan, N., M. Moonmoon and M.M.I. Shah, 2010. Grower's response to mushroom cultivation technologies disseminated by mushroom development project. J. Agric. Soc. Sci., 6: 96-100.
10. J.N. Buah, G.C. Van der Puije, E.A. Bediako, E.A. Abole and F. Showemimo, 2010. The Growth and Yield Performance of Oyster Mushroom (Pleurotus ostreatus) on Different Substrates. Biotechnology, 9: 338-342

11. Kimenju, J.W., G.O.M. Odero, E.W. Mutitu, P.M. Wachira, R.D. Narla and W.M. Muiru, 2009. Suitability of locally available substrates for oyster mushroom (Pleurotus ostreatus) cultivation in Kenya. Asian J. Plant Sci., 8: 510-514

12. Kitamoto, Y., Horkoshi, T., Hosio, N. and Ichikawa, Y. 1995. Nutritional study of fruiting-body formation in Psilocybe panaeoliformis. Trans. Mycol. Soc. (Japan). 16(3): 268.

13. Obodai, M., Kine, J.C.O. and Vowotor, K.A. 2003. Comparative study on the growth and yield of Pleurotus ostreatus mushroom on different lignocellulosic by products. J. Indian Microbial. Biotechnol. 30(3):146-149.

14. Oei, P., 1996. Mushroom Cultivation with Special Emphasis on Appropriate Techniques for Developing Countries. 2nd Edn., Backhuys, Amsterdam, The Netherlands, pp: 111-122

15. Onyango, B.O., V.A. Palapala, P.F. Arama, S.O. Wagai and B.M. Gichumu, 2011. Sustainability of selected supplemented substrates for cultivation of Kenyan native wood ear mushrooms (Auricularia auricula). Am. J. Food. Technol., 6: 395-403.

16. Palapala, V.A., F.P. Miheso and O. Nandi, 2006. Cultivation potential of indigenous species of African wood ear mushrooms. Paper Presented at Masinde Muliro University, Kenya, pp: 1-21

17. Poppe, J.A. 1973. The fruit regulating action of light and chemicals in the culture of P. spp (Fr.) Medeligen, Vande Paculteit Land bouwweten sheappen. 38(3): 1387-1397, (cited from Hort. Abst. 44(2): 1974-9737).

18. Quimio, T.H. 1980. Survey and culture of edible ones, In: cultivation of edible mushroom in tropics, UNESCO, Regional workshop,Manila.

19. Quimio, T.H. and Sardsud, U. 1981. Nutritional requirements of Pleurotus ostreatus (Fr). Philippine Agriculturist. 64(1): 79-89.

20. S. R. Mondal, M. J. Rehana, M. S. Noman and S. K. Adhikary 2010. Comparative study on growth and yield performance of oyster mushroom (Pleurotus florida) on different substrates Agrotechnology Discipline, Khulna University, Khulna-9208, Bangladesh

21. Shah, Z. A., Ashraf and Ishtiaq, M.C. 2004. Comparative study on cultivation and yield performance of Oyster mushroom (Pleurotus ostreatus) on different substrates (wheat straw, Leaves and Sawdust). Pakistan J. Nutrition. 3(3): 158-160

22. Wang, C.W. 1982. Cellulolytacenzymes of Volvariella Volvacea Tropical Mushrooms Biological Nature and cultivation methods (ed.) S.T. Chang and T.H. Quimio, The Chinese University press, Hongkong

23. Zadrazil, F. 1978. Cultivation of Pleurotus. The biology and cultivation of edible mushrooms by S.T. Chang and W.A. Hayes (eds).Academic press INC. Orlando, Florida. 1:62.

24. Zadrazil, F., 1980. Conversion of different plant waste into feed by Basidiomycetes. Eur. J. Appl. Microbiol., 9: 243-248 